Brit. J. vener. Dis. (1958), 34, 137.

\title{
FIGURES AND FANCIES*
}

\author{
BY \\ S. M. LAIRD \\ St. Luke's Clinic and Royal Infirmary, Manchester
}

I regard election as President of this Society as the highest honour open to the venereologist practising in Britain, and this is the measure of my appreciation of being asked to serve in this capacity during the past two years. In general, the presidential duties are not onerous, thanks to the support of our active members, the wise work of our council, and the labours of our Honorary Secretary and Treasurer. To these office-bearers and to all members of our society I wish to record my sincere thanks. It is traditional for our syllabus of meetings to include a Presidential Address, and the choice of subject, at least in my own case, has proved the hardest of the presidential tasks. We are a society of specialists and "knowing more and more about less and less" restricts the breadth, if not the depth, of the field of choice.

When I succeeded Dr. Robert Lees, a distinguished past president of this society, in Manchester, it was apparent that he had in a short time produced there a much needed transformation in the V.D. services. Enthusiastic and well-trained venereologists had been appointed, not only in Manchester itself but also at strategic points throughout this large and denselypopulated region; the structure and equipment of clinic premises had been greatly improved and, perhaps most important of all, the right "atmosphere" of the clinics and the proper approach to the patients had been created. Naturally some problems remained but it was clear that the tools for the job had been provided. Turning from the individual patient to the epidemiologic situation, I found that the control of syphilis was clearly in sight and that in the City of Manchester, the real remaining problems were gonorrhoea, non-gonococcal urethritis, other conditions requiring treatment, and the many individuals seeking reassurance that recent venereal exposure had not resulted in infection. The need for fuller epidemiologic information was clear and by 1955 the collection of the required data had been organized. The case cards were modified to record the patient's nationality and work, the place where

* Presidential Address to the M.S.S.V.D., delivered on Feb. 28, 1958. the consort was met and where exposure took place, whether there was payment in money or kind, and whether the consort was known or unknown. The demographic data so collected during 1956 and 1957 have been analysed and I have chosen to speak to-night about some of the figures and my fancies resulting from this study. The venereal patient is often an unreliable witness and sometimes gives false information even regarding such straightforward items as name, address, and marital status. Nationality can usually be confirmed by appearance and accent, and this information and the diagnosis in these male patients are the only two items in the analysis for which accuracy is claimed. The other items are based on the patients' statements and will certainly be false in some cases. By studying a large sample, however, these inevitable imperfections may perhaps not preclude the discovery of broad trends which may point the direction in which further efforts at V.D. control should be pursued. Narrow conclusions must be avoided and this need for caution in interpretation is implicit in the carefully chosen title of this address.

\section{Material and Analysis}

The two major V.D. centres in Manchester are St. Luke's Clinic in ad hoc premises in the city centre and the Special Clinic at the Royal Infirmary (M.R.I.) which is the main teaching hospital. For male patients there are six morning sessions, two afternoon sessions, and three evening sessions per week at St. Luke's Clinic, while at the M.R.I. there are two evening sessions. Between the two centres, the male patient in Manchester is thus able to obtain advice and treatment on any morning except Sunday and on any week-day evening. Table I gives the total of male patients registered at these two clinics during 1956 and 1957, with the following exceptions:

(a) Patients suffering from syphilis,

(b) Sexual and family contacts of these syphilis patients,

(c) Persons suspected of suffering from syphilis referred from other medical departments but 
found not to be infected, e.g. general hospital in-patient and out-patient consultations, blood donors, and expectant mothers,

(d) Patients transferred from other centres after diagnosis,

(e) Men seeking to exclude infection, in whom no abnormality was found and who denied intercourse during the previous 3 months,

( $f$ ) Male cases admitting homosexual contacts.

TABLE I

TOTAL NUMBER OF MALE CASES, BY DIAGNOSIS, 1956 AND 1957

\begin{tabular}{|c|c|c|c|c|c|}
\hline \multirow{2}{*}{\multicolumn{2}{|c|}{ Diagnosis }} & \multirow{2}{*}{$\begin{array}{l}\text { St. Luke's } \\
\text { Clinic }\end{array}$} & \multirow{2}{*}{$\begin{array}{c}\text { Manchester } \\
\text { Royal } \\
\text { Infirmary }\end{array}$} & \multicolumn{2}{|c|}{ Total } \\
\hline & & & & No. & Per cent. \\
\hline 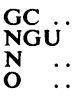 & $\begin{array}{l}\ldots \\
\cdots \\
\cdots\end{array}$ & $\begin{array}{r}1,975 \\
941 \\
898 \\
1,262 \\
\end{array}$ & $\begin{array}{l}689 \\
279 \\
177 \\
367\end{array}$ & $\begin{array}{l}2,664 \\
1,220 \\
1,075 \\
1,629\end{array}$ & $\begin{array}{l}40 \\
19 \\
16 \\
25\end{array}$ \\
\hline Total & . & 5,076 & 1,512 & 6,588 & 100 \\
\hline
\end{tabular}

Syphilis patients, homosexuals, and those transferred from other centres represent only a relatively insignificant proportion of the total cases registered, and the other categories have been excluded because their examination was not prompted by recent venereal exposure.

Of the total of 6,588 cases included in the study (Table I), 40 per cent. had gonorrhoea (GC), 19 per cent. had non-gonococcal urethritis (NGU), 16 per cent. were found to have other conditions requiring treatment (N), and 25 per cent. ("O" cases) either had no abnormality or had some condition not requiring physical treatment (Fig. 1).

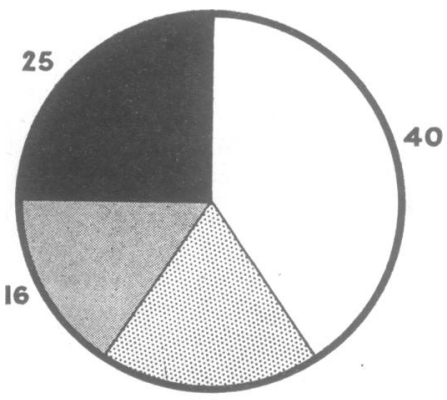

19

Nothing

Other conditions requiring treatment

Non-gonococcal urethritis

Gonorrhoea

FIG. 1.-Diagnosis of all cases (per cent.).
The varied conditions found in 300 consecutive cases in which a diagnosis of "N" was made at St. Luke's Clinic, are summarized in Table II; balanitis (45 per cent.) is the commonest condition and, together with herpes genitalis, condylomata acuminata, and pyogenic and parasitic and other skin conditions, accounts for more than four-fifths of this " $N$ " category. With only a few exceptions, the " $O$ " category comprises men who were worried about V.D. after recent exposure but were found after examination and adequate observation not to be infected. They are valuable in this study in that they provide information on sexual activity which does not result in venereal disease.

TABLE II

CONDITIONS CLASSIFIED AS "N" IN 300 CASES (PERCENTAGE)

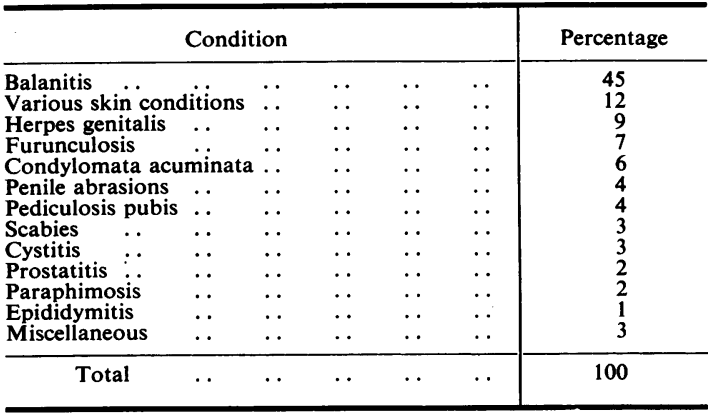

Only a minority of these 6,588 cases has been seen personally; in the majority, the patients have been questioned and dealt with by my colleagues on the medical staff which has not changed during the period of the study. The data recorded are therefore uninfluenced by any preconceived impressions of mine. I am, however, solely responsible for the analysis of the data and for the opinions formed as a result of this study. I have deliberately excluded female patients from this demographic inquiry, as I find that, with only a few exceptions, the female patient is entirely unreliable regarding her sexual activities.

The data were first analysed for each quarter throughout the 2 years. In both clinics, the second and third quarters of each year produced more cases than the first and fourth. This apart, the data for each quarter were so consistent that I present them on a yearly basis to serve simplicity.

Nationality.-Table III and Fig. 2 (opposite) show the nationalities of all the patients studied. The United Kingdom (U.K.) patients were mostly from the Manchester area, but Scots, Welsh, and the few men from Northern Ireland are included. A few coloured 
TABLE III

TOTAL CASES BY NATIONALITY, 1956 AND 1957

\begin{tabular}{|c|c|c|c|c|}
\hline \multirow{2}{*}{ Nationality } & \multirow{2}{*}{$\begin{array}{l}\text { St. Luke's } \\
\text { Clinic }\end{array}$} & \multirow{2}{*}{$\begin{array}{c}\text { Manchester } \\
\text { Royal } \\
\text { Infirmary }\end{array}$} & \multicolumn{2}{|c|}{ Total } \\
\hline & & & No. & $\begin{array}{l}\text { Per } \\
\text { cent. }\end{array}$ \\
\hline $\begin{array}{l}\text { United Kingdom } \\
\text { Eire } \ldots \\
\text { W. Indies } \\
\text { W. Africa } \\
\text { Other Nationalities }\end{array}$ & $\begin{array}{r}3,440 \\
439 \\
528 \\
306 \\
363\end{array}$ & $\begin{array}{l}816 \\
182 \\
292 \\
109 \\
113\end{array}$ & $\begin{array}{r}4,256 \\
621 \\
820 \\
415 \\
476\end{array}$ & $\begin{array}{r}65 \\
9 \\
12 \\
6 \\
7\end{array}$ \\
\hline Total .. & 5,076 & 1,512 & 6,588 & 100 \\
\hline
\end{tabular}

patients from British Honduras and British Guiana are included with those from the British West Indies (W.I.) and with the West Africans (W.A.) form the coloured group of patients. Those grouped under Other Nationalities (O.N.) were chiefly whites from Europe and the Mediterranean area (Cypriots, Greeks, and Maltese).

The two clinics show minor differences. The percentage of U.K. patients is higher at St. Luke's Clinic, and the more cosmopolitan composition at the M.R.I. clinic arises from its situation adjacent to the poor neighbourhood in which most of the coloured people reside. The patients at St. Luke's Clinic are about three times as numerous as those at the M.R.I. clinic and therefore the St. Luke's figures influence the combined series proportionately
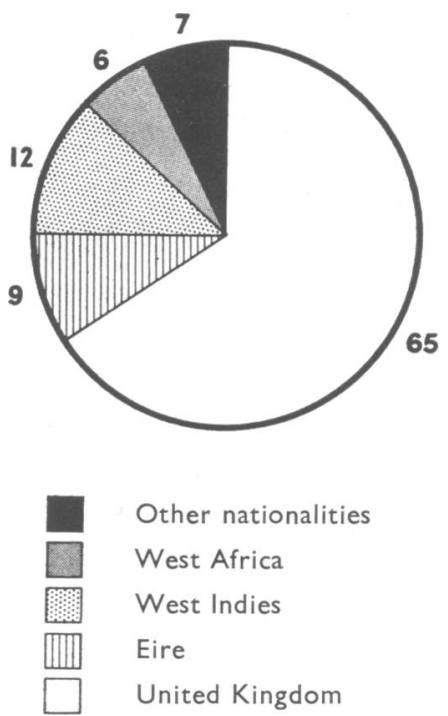

FIG. 2.-Nationality of all cases (per cent.).

more than the M.R.I. figures; where significant differences exist, the figures are given for the two clinics separately as well as for the whole series. Table IV correlates, in percentage form, nationality and diagnosis for the two clinics separately.

TABLE IV

TOTAL CASES BY NATIONALITY AND DIAGNOSIS (PERCENTAGE)

\begin{tabular}{|c|c|c|c|c|c|c|c|c|c|}
\hline Diagnosis & & $\mathrm{Na}$ & onal & & & & St. Luke's Clinic & $\begin{array}{c}\text { Manchester } \\
\text { Royal Infirmary }\end{array}$ & Whole Series \\
\hline \multirow[t]{2}{*}{ Gonorrhoea } & \multirow[t]{2}{*}{$\cdots$} & $\begin{array}{l}\text { United Kingdom } \\
\text { Eire } \\
\text { British West Indies } \\
\text { West Africa } \\
\text { Other nationalities }\end{array}$ & $\begin{array}{l}\cdots \\
\cdots \\
\cdots \\
\cdots\end{array}$ & $\begin{array}{l}\cdots \\
\cdots \\
\cdots \\
\cdots\end{array}$ & $\begin{array}{l}\cdots \\
\cdots \\
\cdots \\
\cdots\end{array}$ & $\begin{array}{l}\cdots \\
\cdots \\
\cdots \\
\cdots\end{array}$ & $\begin{array}{r}50 \\
12 \\
20 \\
12 \\
6\end{array}$ & $\begin{array}{r}39 \\
15 \\
27 \\
11 \\
8\end{array}$ & $\begin{array}{r}47 \\
13 \\
21 \\
12 \\
7\end{array}$ \\
\hline & & Total* $\ldots$ & $\cdots$ & $\cdots$ & $\cdots$ & $\cdots$ & 1,975 & 689 & 2,664 \\
\hline NGU & \multirow[t]{2}{*}{. } & $\begin{array}{l}\text { United Kingdom } \\
\text { Eire } \\
\text { British West Indies } \\
\text { West Africa } \\
\text { Other nationalities }\end{array}$ & $\begin{array}{l}\cdots \\
\cdots \\
\cdots \\
\cdots\end{array}$ & $\begin{array}{l}\cdots \\
\cdots \\
\cdots \\
\cdots\end{array}$ & $\begin{array}{l}\cdots \\
\cdots \\
\cdots \\
\cdots\end{array}$ & $\begin{array}{l}\cdots \\
\cdots \\
\cdots \\
\cdots\end{array}$ & $\begin{array}{r}72 \\
6 \\
10 \\
5 \\
7\end{array}$ & $\begin{array}{r}57 \\
8 \\
20 \\
7 \\
8\end{array}$ & $\begin{array}{r}69 \\
6 \\
12 \\
5 \\
8\end{array}$ \\
\hline NGU & & Total $^{*} \quad \ldots \quad \ldots$ & $\ldots$ & . & $\cdots$ & $\cdots$ & 941 & 279 & 1,220 \\
\hline \multirow[t]{2}{*}{$\cdots$} & \multirow[t]{2}{*}{. } & $\begin{array}{l}\text { United Kingdom } \\
\text { Eire } \\
\text { British West Indies } \\
\text { West Africa } \\
\text { Other nationalities }\end{array}$ & $\begin{array}{l}\cdots \\
\cdots \\
\cdots \\
\cdots\end{array}$ & $\begin{array}{l}\cdots \\
\cdots \\
\cdots \\
\cdots\end{array}$ & $\begin{array}{l}\cdots \\
\cdots \\
\cdots \\
\cdots\end{array}$ & $\begin{array}{l}\cdots \\
\cdots \\
\cdots \\
\cdots\end{array}$ & $\begin{array}{r}75 \\
10 \\
4 \\
2 \\
9\end{array}$ & $\begin{array}{r}63 \\
14 \\
13 \\
2 \\
9\end{array}$ & $\begin{array}{r}73 \\
10 \\
5 \\
2 \\
10\end{array}$ \\
\hline & & Total* $\ldots$ & $\cdots$ & $\cdots$ & $\cdots$ & $\cdots$ & 898 & 177 & 1,075 \\
\hline \multirow[t]{2}{*}{$\mathbf{O}$} & \multirow[t]{2}{*}{. } & $\begin{array}{l}\text { United Kingdom } \\
\text { Eire } \\
\text { British West Indies } \\
\text { West Africa } \\
\text { Other nationalities }\end{array}$ & $\begin{array}{l}\cdots \\
\cdots \\
\cdots \\
\cdots\end{array}$ & $\begin{array}{l}\cdots \\
\cdots \\
\cdots \\
\cdots\end{array}$ & $\begin{array}{l}\cdots \\
\cdots \\
\cdots \\
\cdots\end{array}$ & $\begin{array}{l}\cdots \\
\cdots \\
\cdots \\
\cdots\end{array}$ & $\begin{array}{r}86 \\
6 \\
1 \\
1 \\
6\end{array}$ & $\begin{array}{r}75 \\
8 \\
7 \\
2 \\
8\end{array}$ & $\begin{array}{r}84 \\
6 \\
3 \\
1 \\
6\end{array}$ \\
\hline & & Total $^{*} \quad \ldots$ & $\ldots$ & . & . & $\ldots$ & 1,262 & 367 & 1,629 \\
\hline Grand Total* & $\cdots$ & $\cdots$ & $\cdots$ & $\cdots$ & $\cdots$ & $\cdots$ & 5,076 & 1,512 & 6,588 \\
\hline
\end{tabular}


Fig. 3 correlates nationality and diagnosis for the whole series.

(1) Half the gonococcal infections occur in persons born outside the U.K.

(2) West Indians and West Africans account for onethird of all gonococcal infections.

(3) One-fifth of gonococcal infections occur in citizens from Eire and whites from other European countries.

(4) The clientèle at the M.R.I. clinic is more cosmopolitan than that at St. Luke's Clinic.

(5) N.G.U. appears to be much more common in men from the U.K. and from the continent of Europe than in those from Eire, the West Indies, and West Africa.

(6) Only one in every twenty patients classified as "N" or " $\mathrm{O}$ " is coloured.

(7) Over four-fifths of the "O" patients were from the U.K.
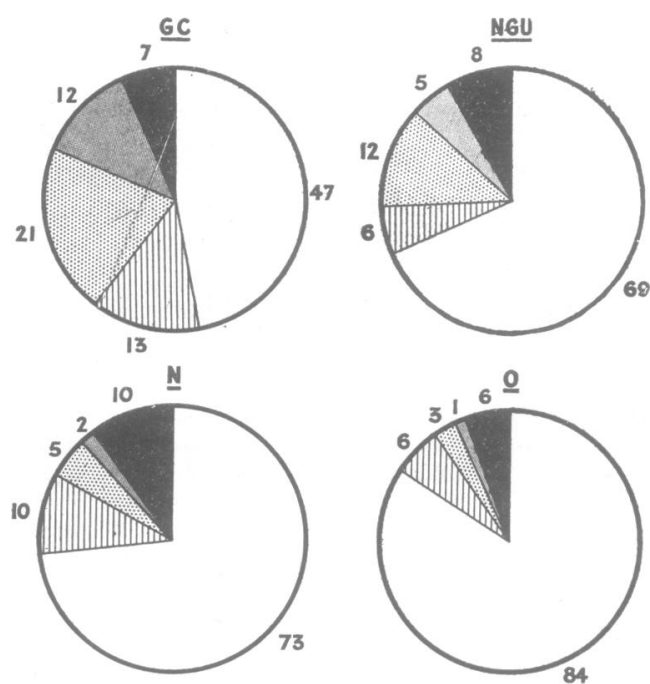

Other nationalities

West Africa

West Indies

Eire

United Kingdom

FIG. 3.-Nationality and Diagnosis of all cases (per cent.).

Age Distribution.-Table $\mathrm{V}$ gives the percentage age distribution for the whole series and also for the four diagnostic categories. As 65 per cent. of all the patients in the whole series belong to the U.K. (Table III), the effect of compulsory national service must be remembered; 3 per cent. for the under 20 age group is clearly lower than would be the case if U.K. men in this age group were all in civilian life. Even so, four-fifths of gonorrhoea cases are under 35 years of age. The greatest number of cases came from the 25 to 29-year group, while the age distribution for N.G.U. runs about 5 years later than that of gonorrhoea. Patients aged 50 and over seldom have gonorrhoea, occasionally have N.G.U., but more frequently attend with anxiety over a recent extramarital exposure to infection.

TABLE V

AGE AND DIAGNOSIS IN WHOLE SERIES (PERCENTAGE)

\begin{tabular}{|c|c|c|c|c|c|}
\hline \multirow{2}{*}{$\underset{\text { (yrs) }}{\text { Age Group }}$} & \multicolumn{5}{|c|}{ Diagnosis } \\
\hline & GC & NGU & $\mathbf{N}$ & $\mathbf{O}$ & Total \\
\hline Under 20 & 3 & 3 & 5 & 3 & 3 \\
\hline $20-24$ & 23 & 16 & 19 & 18 & 20 \\
\hline $25-29$ & 30 & 23 & 21 & 21 & 25 \\
\hline $30-34$ & 22 & 21 & 18 & 22 & 21 \\
\hline 35-39 & 11 & 15 & 12 & 14 & 13 \\
\hline $40-44$ & 6 & 10 & 10 & 9 & 8 \\
\hline $45-49$ & 3 & 6 & 7 & 5 & 5 \\
\hline $50-54$ & 1 & 2 & 3 & 4 & 2 \\
\hline $55-59$ & $0 \cdot 3$ & 2 & 2 & 3 & 2 \\
\hline 60 and Over & $0 \cdot 2$ & 0.5 & 3 & 2 & 1 \\
\hline
\end{tabular}

Marital Status.-For the purpose of this study of the venereal patient, widowers and husbands divorced or legally separated from their wives have been grouped together as "Others". In coloured patients, and especially the West Africans, information about marital status is particularly unreliable. The men from Eire are mostly young and, although in steady employment and earning good wages, still observe the Irish tradition of marrying late. The Europeans of other nationalities are usually young and single and are not a representative sample. In consequence, the analysis of marital status by disease category (Table VI; Fig. 4, opposite) refers to U.K. patients

TABLE VI

MARITAL STATUS, U.K. PATIENTS ONLY, BY DIAGNOSIS, 1956 AND 1957 (PERCENTAGE)

\begin{tabular}{cc|r|r|r|r|r}
\hline \multirow{2}{*}{ Marital } & \multirow{2}{*}{ Status } & \multicolumn{5}{|c}{ Diagnosis } \\
\cline { 3 - 7 } & & GC & NGU & N & O & Total \\
\hline Single & $\ldots$ & 58 & 52 & 53 & 47 & 52 \\
Married & $\cdots$ & 33 & 42 & 41 & 48 & 41 \\
Others & $\cdots$ & 9 & 6 & 6 & 5 & 6 \\
\hline \multicolumn{1}{|c|}{ Total } & $\cdots$ & 100 & 100 & 100 & 100 & 100 \\
\hline
\end{tabular}

only. One-third of the gonorrhoea patients were married, as were half the " $O$ " cases, and these findings suggest that there is probably a substantial amount of extramarital exposure amongst at least certain sections of married U.K. males. The relatively high rate of N.G.U. in married men accords with clinical impression. It is interesting that the pattern for 


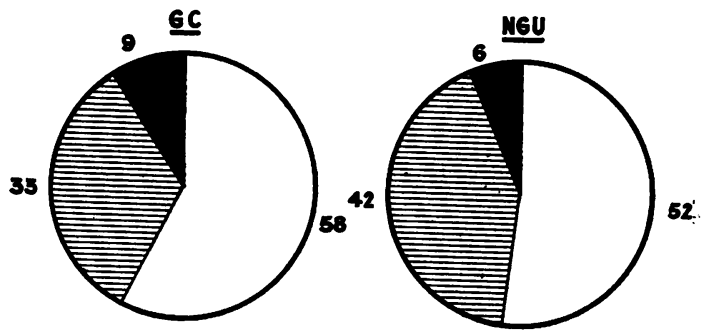

Meeting Place.-The place where the female consort was met is shown for the M.R.I. and St. Luke's Clinic in Table VII and for the whole series in Fig. 5 and Table VIII (overleaf).

The following points emerge:

(1) Three-quarters met their consorts casually in the street or public house; about 45 per cent. in the former and about 30 per cent. in the latter.

(2) Almost one-fifth met their consorts casually in clubs and dance halls.
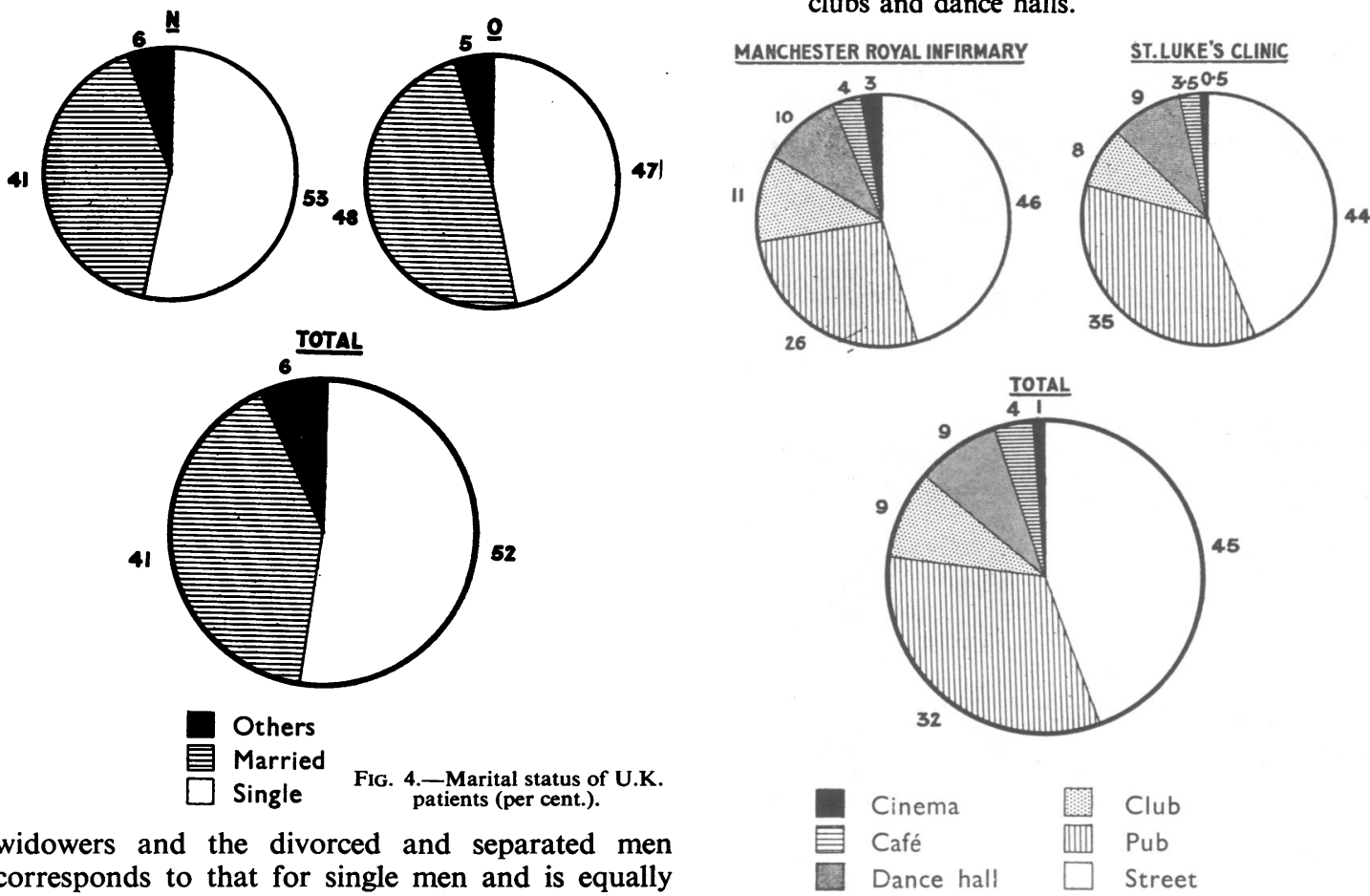

widowers and the divorced and separated men corresponds to that for single men and is equally distinct from that of the married group.

FIG. 5.-Meeting place (per cent.).

TABLE VII

MEETING PLACE, BY DIAGNOSIS (PERCENTAGE)

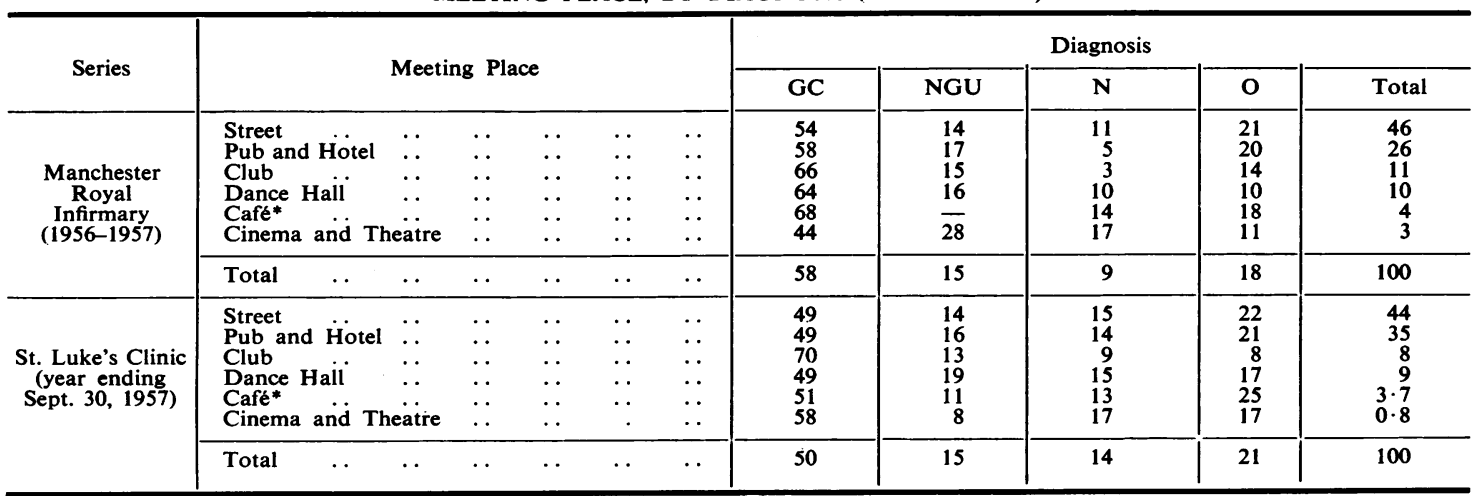

* Includes restaurant, milk-bar, and coffee stall 
TABLE VIII

MEETING PLACE, BY DIAGNOSIS, FOR WHOLE SERIES (NUMBER AND PERCENTAGE)

\begin{tabular}{|c|c|c|c|c|c|c|c|c|c|c|}
\hline \multirow{3}{*}{ Meeting Place } & \multicolumn{10}{|c|}{ Diagnosis } \\
\hline & \multicolumn{2}{|c|}{$\overline{\text { GC }}$} & \multicolumn{2}{|c|}{ NGU } & \multicolumn{2}{|c|}{$\mathbf{N}$} & \multicolumn{2}{|r|}{ O } & \multicolumn{2}{|c|}{ Total } \\
\hline & No. & Per cent. & No. & Per cent. & No. & Per cent. & No. & Per cent. & No. & Per cent. \\
\hline $\begin{array}{l}\text { Street } \ldots \\
\text { Pub and Hotel } \\
\text { Club } \\
\text { Dance Hall } \\
\text { Cafe* } \\
\text { Cinema and theatre }\end{array}$ & $\begin{array}{r}525 \\
375 \\
141 \\
116 \\
47 \\
15\end{array}$ & $\begin{array}{l}51 \\
51 \\
69 \\
55 \\
57 \\
50\end{array}$ & $\begin{array}{r}144 \\
119 \\
28 \\
38 \\
6 \\
6\end{array}$ & $\begin{array}{r}14 \\
16 \\
14 \\
18 \\
7 \\
20\end{array}$ & $\begin{array}{r}140 \\
83 \\
13 \\
28 \\
11 \\
5\end{array}$ & $\begin{array}{r}14 \\
11 \\
6 \\
13 \\
13 \\
17\end{array}$ & $\begin{array}{r}218 \\
153 \\
21 \\
30 \\
19 \\
4\end{array}$ & $\begin{array}{l}21 \\
21 \\
10 \\
14 \\
23 \\
13\end{array}$ & $\begin{array}{r}1,027 \\
730 \\
203 \\
212 \\
83 \\
30\end{array}$ & $\begin{array}{r}45 \\
32 \\
9 \\
9 \\
4 \\
1\end{array}$ \\
\hline Total & 1,219 & 53 & 341 & 15 & 280 & 12 & 445 & 19 & 2,285 & 100 \\
\hline
\end{tabular}

* Includes restaurant, milk-bar, and coffee stall.

(3) Only about one in every twenty ( 5 per cent.) met his consort in café, restaurant, milk-bar, coffee stall, cinema, or theatre.

(4) Irrespective of the place of meeting, the percentage distribution of conditions found in these male patients (Fig. 6) is remarkably similar.
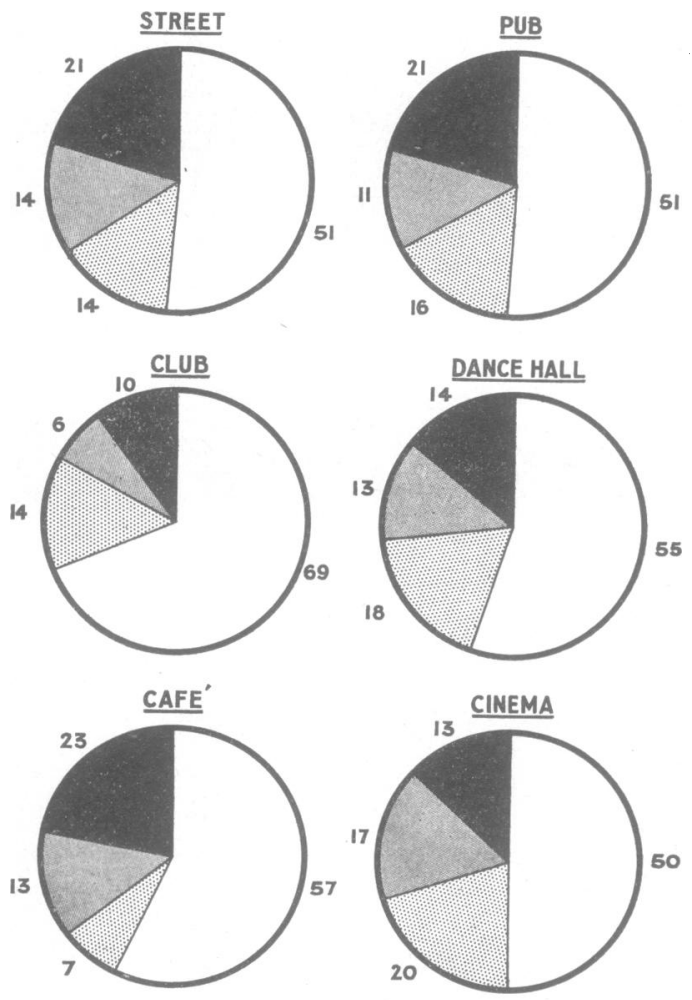

Nothing

Other conditions requiring treatment

Non-gonococcal Urethritis

Gonorrhoea

FIG. 6.-Meeting place and diagnosis (per cent.)
(5) The clubs are patronized almost exclusively by coloured patients (Table IX, opposite) whose diagnostic pattern is characterized by a high rate for gonorrhoea and low rates for N.G.U., "N", and " $O$ " cases.

Place of Exposure.-The place where exposure took place is shown for the M.R.I. and St. Luke's Clinic in Table X (opposite), and for the whole series in Fig. 7.

(1) In the majority exposure took place outside (for M.R.I. patients two-thirds and for St. Luke's patients three-quarters).

(2) Exposure in "her room", which represents almost exclusively the more expensive prostitute, occurred in only about 15 per cent. of male cases and resulted in somewhat less gonorrhoea than when exposure occurred outside.

(3) Men taking the consort to "his room" were usually coloured (Table XI, overleaf) and the women were mostly low-class prostitutes; these two factors explain the different disease pattern in this group. Coloured patients, especially West Indians, usually live in one room (and perhaps share it with a compatriot) in a house where all the rooms are similarly let out to coloured tenants. In such a house the other occupants do not object to a woman being taken into his room.
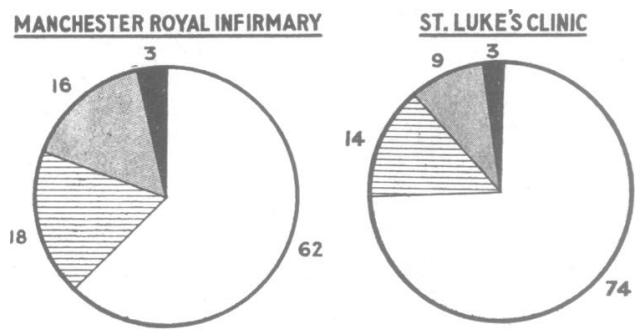

\section{Car, etc. \\ His room \\ Her room \\ Outside}

Fig. 7.-Place of exposure (per cent.). 
TABLE IX

MEETING PLACE, BY DIAGNOSIS AND NATIONALITY, WHOLE SERIES, 1956-57 (PERCENTAGE)

\begin{tabular}{|c|c|c|c|c|c|c|c|c|}
\hline \multirow{2}{*}{ Diagnosis } & \multirow{2}{*}{\multicolumn{2}{|c|}{ Nationality }} & \multicolumn{6}{|c|}{ Meeting Place } \\
\hline & & & Street & Pub and Hotel & Club & Dance Hall & Café* & Cinema and Theatre \\
\hline \multirow[t]{2}{*}{ Gonorrhoea } & $\begin{array}{l}\text { United Kingdom } \\
\text { Eire } \ldots \\
\text { British West Indies } \\
\text { West Africa } 0 \\
\text { Other Nationalities }\end{array}$ & $\begin{array}{l}\cdots \\
\cdots \\
\cdots \\
\cdots\end{array}$ & $\begin{array}{r}42 \\
15 \\
24 \\
12 \\
7\end{array}$ & $\begin{array}{r}57 \\
17 \\
15 \\
7 \\
4\end{array}$ & $\begin{array}{r}9 \\
2 \\
50 \\
37 \\
1\end{array}$ & $\begin{array}{r}43 \\
27 \\
16 \\
6 \\
8\end{array}$ & $\begin{array}{r}45 \\
6 \\
21 \\
18 \\
9\end{array}$ & $\begin{array}{r}66 \\
8 \\
13 \\
13 \\
-\end{array}$ \\
\hline & Totalt $\ldots$ & $\ldots$ & 525 & 375 & 141 & 116 & 47 & 15 \\
\hline \multirow[t]{2}{*}{ NGU } & $\begin{array}{l}\text { United Kingdom } \\
\text { Eire } \\
\text { British West Indies } \\
\text { West Africa } \\
\text { Other nationalities }\end{array}$ & $\begin{array}{l}\cdots \\
\cdots \\
\cdots \\
\cdots\end{array}$ & $\begin{array}{r}63 \\
10 \\
14 \\
6 \\
7\end{array}$ & $\begin{array}{r}65 \\
13 \\
9 \\
3 \\
10\end{array}$ & $\begin{array}{l}\frac{18}{43} \\
39 \\
-\end{array}$ & $\begin{array}{l}53 \\
13 \\
16 \\
18\end{array}$ & $\frac{66}{17}$ & $\begin{array}{l}33 \\
50 \\
17 \\
-\end{array}$ \\
\hline & Totalt $\ldots \quad \ldots$ & .. & 144 & 119 & 28 & 38 & 6 & 6 \\
\hline \multirow[t]{2}{*}{$\mathbf{N} \ldots$} & $\begin{array}{l}\text { United Kingdom } \\
\text { Eire } \\
\text { British West Indies } \\
\text { West Africa } \\
\text { Other nationalities }\end{array}$ & $\begin{array}{l}\cdots \\
\cdots \\
\cdots \\
\cdots\end{array}$ & $\begin{array}{r}69 \\
16 \\
4 \\
4 \\
6\end{array}$ & $\begin{array}{r}72 \\
16 \\
6 \\
1 \\
5\end{array}$ & $\begin{array}{r}54 \\
31 \\
7 \\
7\end{array}$ & $\begin{array}{r}57 \\
29 \\
7 \\
7\end{array}$ & $\begin{array}{r}55 \\
27 \\
9 \\
9 \\
\end{array}$ & $\begin{array}{l}100 \\
- \\
-\end{array}$ \\
\hline & Totalt $\ldots$ & $\ldots$ & 140 & 83 & 13 & 28 & 11 & 5 \\
\hline \multirow[t]{2}{*}{$\mathbf{O}$} & $\begin{array}{l}\text { United Kingdom } \\
\text { Eire } \\
\text { British West Indies } \\
\text { West Africa } \\
\text { Other nationalities }\end{array}$ & $\begin{array}{l}\cdots \\
\cdots \\
\cdots \\
\cdots\end{array}$ & $\begin{array}{r}81 \\
9 \\
3 \\
7\end{array}$ & $\begin{array}{r}87 \\
8 \\
1 \cdot 3 \\
0 \cdot 7 \\
3\end{array}$ & $\begin{array}{l}62 \\
10 \\
10 \\
19 \\
-\end{array}$ & $\begin{array}{r}83 \\
7 \\
7 \\
3\end{array}$ & $\begin{array}{l}74 \\
\frac{11}{15}\end{array}$ & $\begin{array}{l}100 \\
= \\
-\end{array}$ \\
\hline & Totalt $\ldots$ & $\ldots$ & 218 & 153 & 21 & 30 & 19 & 4 \\
\hline Grand Totalt & $\ldots$ & $\ldots$ & 1,027 & 730 & 203 & 212 & 83 & 30 \\
\hline
\end{tabular}

* Includes restaurant, milk bar, and coffee stall.

† Actual numbers.

TABLE X

PLACE OF EXPOSURE, BY DIAGNOSIS (PERCENTAGE)

\begin{tabular}{|c|c|c|c|c|c|c|c|c|c|c|c|}
\hline \multirow{2}{*}{ Series } & \multirow{2}{*}{\multicolumn{6}{|c|}{ Place of Exposure }} & \multicolumn{5}{|c|}{ Diagnosis } \\
\hline & & & & & & & GC & NGU & $\mathbf{N}$ & 0 & Total \\
\hline \multirow[t]{2}{*}{$\begin{array}{c}\text { Manchester } \\
\text { Royal } \\
\text { Infirmary } \\
(1956-57)\end{array}$} & $\begin{array}{l}\text { Outside } \\
\text { Her room } \\
\text { His room . . } \\
\text { Car, taxi, lorry }\end{array}$ & $\begin{array}{l}\cdots \\
\cdots \\
\cdots\end{array}$ & $\begin{array}{l}\cdots \\
\cdots \\
\cdots\end{array}$ & $\begin{array}{l}\cdots \\
\cdots \\
\cdots\end{array}$ & $\begin{array}{l}\cdots \\
\cdots \\
\cdots\end{array}$ & $\begin{array}{l}\cdots \\
\cdots \\
\cdots\end{array}$ & $\begin{array}{l}58 \\
46 \\
70 \\
33\end{array}$ & $\begin{array}{l}13 \\
20 \\
18 \\
29\end{array}$ & $\begin{array}{r}10 \\
12 \\
7 \\
5\end{array}$ & $\begin{array}{r}19 \\
22 \\
5 \\
33\end{array}$ & $\begin{array}{r}62 \\
18 \\
16 \\
3\end{array}$ \\
\hline & Total & . & $\cdots$ & . & . & . & 57 & 16 & 10 & 17 & 100 \\
\hline \multirow[t]{2}{*}{$\begin{array}{l}\text { St. Luke's Clinic } \\
\text { (Year ending } \\
\text { Sept 30, 1957) }\end{array}$} & $\begin{array}{l}\text { Outside } . . \\
\text { Her room.. } \\
\text { His room } \\
\text { Car, taxi, lorry }\end{array}$ & $\begin{array}{l}\cdots \\
\cdots \\
\cdots\end{array}$ & $\begin{array}{l}\ddot{*} \\
\ddot{*}\end{array}$ & $\begin{array}{l}\ddot{ } \\
\cdots \\
\cdots\end{array}$ & $\begin{array}{l}\ddot{ } \\
\cdots \\
\cdots\end{array}$ & $\begin{array}{l}\cdots \\
\cdots \\
\cdots\end{array}$ & $\begin{array}{l}47 \\
40 \\
59 \\
28\end{array}$ & $\begin{array}{l}18 \\
15 \\
19 \\
36\end{array}$ & $\begin{array}{l}15 \\
17 \\
10 \\
10\end{array}$ & $\begin{array}{l}20 \\
28 \\
12 \\
26\end{array}$ & $\begin{array}{r}74 \\
14 \\
9 \\
3\end{array}$ \\
\hline & Total & $\ldots$ & $\ldots$ & $\ldots$ & $\ldots$ & $\ldots$ & 47 & 18 & 14 & 21 & 100 \\
\hline
\end{tabular}

Type of Consort.-The female consorts have been divided into four categories (Table XII and Fig. 8, overleaf). The following findings emerge:

(1) One-third of the patients paid the woman in money.

(2) One-fifth of the patients paid the woman in kind.

(3) The remaining 45 per cent. paid nothing, and in about half of the free exposures the consort was previously known.

(4) The incidence of gonorrhoea was highest in the groups in which the consort was paid in cash or kind and lowest where exposure was free with a known consort.

(5) The highest N.G.U. rate followed exposure with known consorts.
(6) Worry about the risk of V.D. ("O" cases) occurred as frequently after free exposure with an unknown consort as after intercourse with a prostitute. Less anxiety appeared to be aroused when payment was in kind but such confidence was often misplaced so far as gonococcal infection was concerned.

Geography of Exposure.-87 per cent. of the exposures had taken place in Manchester or its immediate environs, 10 per cent. in other parts of the U.K., and in 3 per cent. abroad (Table XIII, overleaf). Thus the problem of controlling V.D. in Manchester is almost entirely a local one, and the 
TABLE XI

PLACE OF EXPOSURE, BY DIAGNOSIS AND NATIONALITY (PERCENTAGE)

\begin{tabular}{|c|c|c|c|c|c|c|c|c|c|c|}
\hline \multirow{4}{*}{ Diagnosis } & \multirow{4}{*}{ Nationality } & & \multicolumn{8}{|c|}{ Series } \\
\hline & & & \multicolumn{4}{|c|}{ St. Luke's Clinic } & \multicolumn{4}{|c|}{ Manchester Royal Infirmary } \\
\hline & & & \multicolumn{8}{|c|}{ Place of Exposure } \\
\hline & & & Outside & Her Room & His Room & $\underset{\text { Lorry }}{\text { Car, Taxi, }}$ & Outside & Her Room & His Room & $\underset{\text { Lorry }}{\text { Car, Taxi, }}$ \\
\hline \multirow[t]{2}{*}{ Gonorrhoea } & $\begin{array}{l}\text { United Kingdom .. } \\
\text { Eire } \\
\text { British West Indies } \\
\text { West Africa } \\
\text { Other Nationalities }\end{array}$ & $\begin{array}{l}\cdots \\
\cdots \\
\cdots\end{array}$ & $\begin{array}{r}54 \\
12 \\
19 \\
10 \\
4\end{array}$ & $\begin{array}{r}50 \\
15 \\
17 \\
10 \\
8\end{array}$ & $\begin{array}{r}20 \\
8 \\
43 \\
26 \\
3\end{array}$ & $\begin{array}{r}81 \\
6 \\
6 \\
6 \\
-\end{array}$ & $\begin{array}{r}44 \\
26 \\
19 \\
5 \\
6\end{array}$ & $\begin{array}{r}36 \\
12 \\
34 \\
11 \\
7\end{array}$ & $\begin{array}{r}9 \\
59 \\
26 \\
6\end{array}$ & $\frac{100}{-}$ \\
\hline & Total $^{*} \quad \ldots$ & $\cdots$ & 691 & 109 & 105 & 16 & 293 & 73 & 93 & 7 \\
\hline \multirow[t]{2}{*}{ NGU } & $\begin{array}{l}\text { United Kingdom . } \\
\text { Eire } \\
\text { British West Indies } \\
\text { West Africa } \\
\text { Other nationalities }\end{array}$ & $\begin{array}{l}\cdots \\
\cdots \\
\cdots \\
\cdots\end{array}$ & $\begin{array}{r}75 \\
7 \\
8 \\
4 \\
6 \\
\end{array}$ & $\begin{array}{r}58 \\
5 \\
15 \\
5 \\
17 \\
\end{array}$ & $\begin{array}{r}\frac{33}{52} \\
6 \\
9\end{array}$ & $\begin{array}{r}95 \\
5 \\
- \\
-\end{array}$ & $\begin{array}{r}53 \\
21 \\
13 \\
3 \\
10 \\
\end{array}$ & $\begin{array}{r}56 \\
10 \\
26 \\
2 \\
10 \\
\end{array}$ & $\begin{array}{r}8 \\
4 \\
58 \\
22 \\
8 \\
\end{array}$ & $\begin{array}{l}100 \\
\overline{-} \\
\end{array}$ \\
\hline & $\cdots \quad \ldots$ & $\cdots$ & 258 & 40 & 33 & 21 & 68 & 31 & 24 & 6 \\
\hline \multirow[t]{2}{*}{$\mathbf{N}$} & $\begin{array}{l}\text { United Kingdom .. } \\
\text { Eire } \\
\text { British West Indies } \\
\text { West Africa } \\
\text { Other nationalities }\end{array}$ & $\begin{array}{l}\cdots \\
\cdots \\
\cdots \\
\cdots\end{array}$ & $\begin{array}{r}71 \\
14 \\
6 \\
3 \\
6\end{array}$ & $\begin{array}{r}66 \\
7 \\
2 \\
7 \\
18\end{array}$ & $\frac{65}{\frac{12}{24}}$ & $\frac{100}{E}$ & $\begin{array}{r}59 \\
31 \\
6 \\
4\end{array}$ & $\frac{84}{11}$ & $\begin{array}{l}22 \\
11 \\
44 \\
11 \\
11\end{array}$ & $\frac{100}{-}$ \\
\hline & Total $^{*} \quad \ldots$ & $\cdots$ & 215 & 45 & 17 & 6 & 49 & 19 & 9 & 1 \\
\hline \multirow[t]{2}{*}{$\mathbf{O}$} & $\begin{array}{l}\text { United Kingdom . } \\
\text { Eire } \\
\text { British West Indies } \\
\text { West Africa } \\
\text { Other nationalities }\end{array}$ & $\begin{array}{l}\cdots \\
\cdots \\
\cdots \\
\cdots\end{array}$ & $\begin{array}{r}86 \\
7 \\
1 \\
0 \cdot 6 \\
6\end{array}$ & $\begin{array}{r}81 \\
6 \\
3 \\
3 \\
8\end{array}$ & $\begin{array}{l}77 \\
\bar{Z} \\
23\end{array}$ & $\frac{87}{-}$ & $\begin{array}{r}77 \\
14 \\
5 \\
4\end{array}$ & $\begin{array}{r}69 \\
17 \\
8 \\
3 \\
3\end{array}$ & $\begin{array}{l}16 \\
16 \\
16 \\
33 \\
16\end{array}$ & $\begin{array}{l}100 \\
- \\
-\end{array}$ \\
\hline & Total* & $\cdots$ & 303 & 78 & 22 & 15 & 95 & 35 & 6 & 7 \\
\hline Grand Total* & $\cdots$ & $\cdots$ & 1,467 & 272 & 177 & 58 & 505 & 158 & 132 & 21 \\
\hline
\end{tabular}

* Actual_numbers.

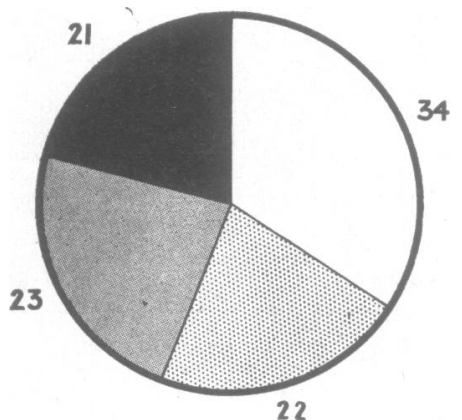

22

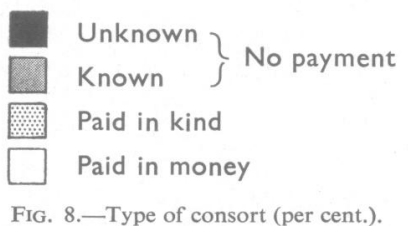

importation of infection is insignificant. That this is not the case with regard to syphilis has been shown elsewhere (Laird, 1957).
TABLE XII 1956 AND 1957 (PERCENTAGE)

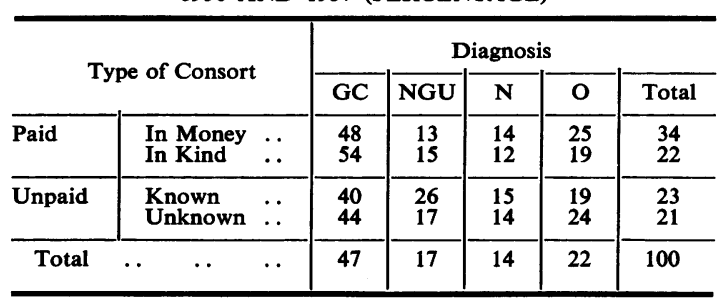

TABLE XIII

GEOGRAPHICAL PLACE OF EXPOSURE, 1956 AND 1957 (NUMBER AND PERCENTAGE)

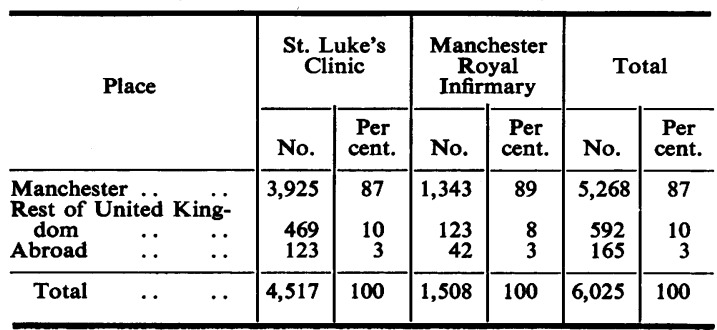


Day of Exposure.-An attempt was made to discover on what day of the week sexual activity was greatest. Gonorrhoea cases were selected for this purpose because almost all males with gonorrhoea report quickly for treatment and, with the short and welldefined incubation period, can usually remember the date of the exposure. The findings in $\mathbf{3 2 6}$ male cases of gonorrhoea in which I was personally able to record the definite dates of exposure show that Friday, Saturday, and Sunday are the days of greatest sexual activity-20, 22, and 16 per cent. respectively (Table XIV and Fig. 9).

TABLE XIV

DAY OF EXPOSURE OF GONORRHOEA CASES

\begin{tabular}{|c|c|c|c|c|c|c|}
\hline \multirow{2}{*}{\multicolumn{5}{|c|}{ Day of the Week }} & \multicolumn{2}{|c|}{ Gonorrhoea Cases } \\
\hline & & & & & \multirow{2}{*}{$\begin{array}{c}\text { Number } \\
26 \\
40 \\
33 \\
39 \\
64 \\
72 \\
52\end{array}$} & \multirow{2}{*}{$\begin{array}{c}\text { Percentage } \\
8 \\
12 \\
10 \\
12 \\
20 \\
22 \\
16\end{array}$} \\
\hline $\begin{array}{l}\text { Monday } \\
\text { Tuesday } \\
\text { Wednesday } \\
\text { Thursday } \\
\text { Friday . . } \\
\text { Saturday } \\
\text { Sunday . . }\end{array}$ & $\begin{array}{l}\ldots \\
\cdots \\
\cdots \\
\cdots \\
\cdots\end{array}$ & $\begin{array}{l}\cdots \\
\cdots \\
\cdots \\
\cdots \\
\cdots \\
\cdots\end{array}$ & $\begin{array}{l}\cdots \\
\cdots \\
\cdots \\
\cdots \\
\cdots\end{array}$ & $\begin{array}{l}\ldots \\
\ldots \\
\cdots \\
\cdots \\
\cdots\end{array}$ & & \\
\hline Total & . & .. & .. & . & 326 & 100 \\
\hline
\end{tabular}

Incubation Period of Gonorrhoea.-In 295 male cases of gonorrhoea, I was able to note the exact date of the relevant exposure and of the appearance of the urethral discharge (Table XV and Fig. 10). In 60 per cent. the incubation period was between 2 and 4 days inclusive; in 5 per cent. it seemed to be over 10 days.

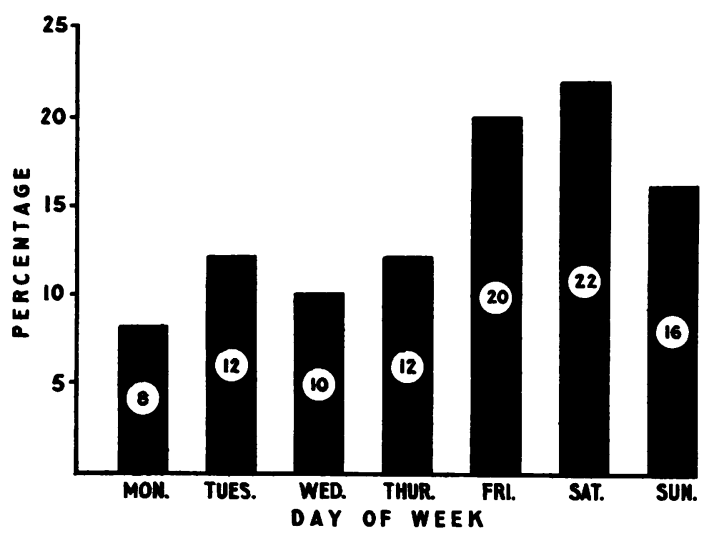

Fig. 9.-Day of exposure.

TABLE XV

INCUBATION PERIOD OF GONORRHOEA (DAYS)

\begin{tabular}{c|c|c}
\hline \multirow{2}{*}{$\begin{array}{c}\text { Incubation Period } \\
\text { (days) }\end{array}$} & \multicolumn{2}{|c}{ Gonorrhoea Cases } \\
\cline { 2 - 3 } & Number & Percentage \\
\hline 1 & 4 & 1 \\
2 & 67 & 23 \\
3 & 62 & 21 \\
4 & 36 & 16 \\
5 & 24 & 11 \\
6 & 18 & 6 \\
7 & 11 & 4 \\
8 & 7 & 2 \\
9 & 9 & 3 \\
10 & 15 & 5 \\
Over 10 & 295 & 100 \\
\hline Total $\quad .$. & $\ldots$ &
\end{tabular}

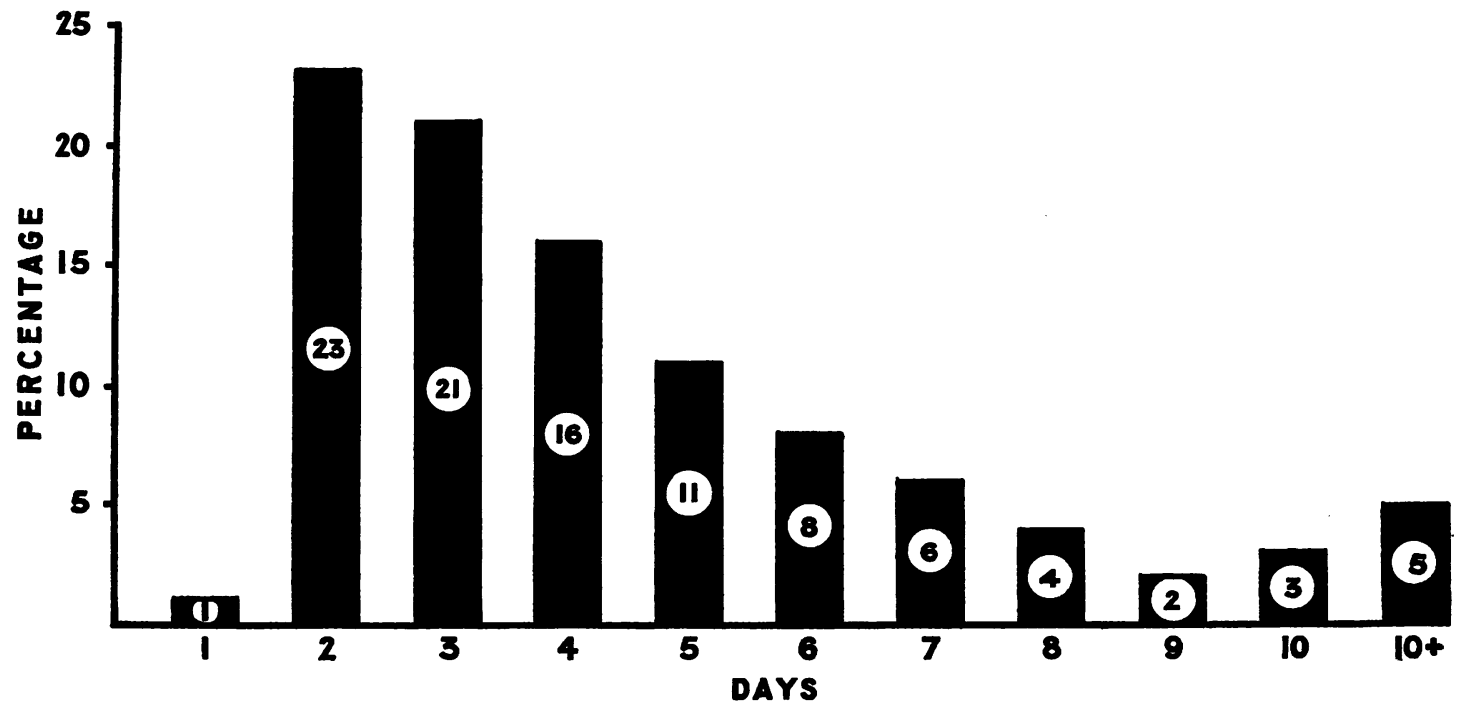

Fig. 10.-Incubation period of Gonorrhoea. 
Gonorrhoea/Non-Gonococcal Urethritis Ratio.-The GC/NGU ratio is shown by nationality for the M.R.I., St. Luke's Clinic, and the whole Manchester series (Table XVI).

TABLE XVI

GC/NGU RATIOS, BY NATIONALITY (PERCENTAGE)

\begin{tabular}{|c|c|c|c|c|}
\hline Nationality & & $\begin{array}{l}\text { St. Luke's } \\
\text { Clinic }\end{array}$ & $\begin{array}{c}\text { Manchester } \\
\text { Royal } \\
\text { Infirmary }\end{array}$ & $\begin{array}{l}\text { Whole } \\
\text { Series }\end{array}$ \\
\hline All Nationalities & . & $2 \cdot 09$ & $2 \cdot 47$ & $2 \cdot 18$ \\
\hline $\begin{array}{l}\text { United Kingdom } \\
\text { Eire } . . \\
\text { W. Indies } \\
\text { W. Africa } \\
\text { Other Nationalities }\end{array}$ & $\begin{array}{l}\cdots \\
\cdots \\
\cdots \\
\cdots\end{array}$ & $\begin{array}{l}1 \cdot 46 \\
4 \cdot 38 \\
4 \cdot 33 \\
5 \cdot 33 \\
1 \cdot 76\end{array}$ & $\begin{array}{l}1 \cdot 68 \\
4 \cdot 56 \\
3 \cdot 36 \\
4 \cdot 11 \\
2 \cdot 33\end{array}$ & $\begin{array}{l}1 \cdot 50 \\
4 \cdot 44 \\
3 \cdot 96 \\
4 \cdot 95 \\
1 \cdot 89\end{array}$ \\
\hline
\end{tabular}

Table XVI and Fig. 11 show that:

(1) The GC/NGU ratios for white patients were higher at the M.R.I. than at St. Luke's Clinic.

(2) U.K. patients had the lowest and the West Africans had the highest ratio.

(3) European other nationalities (O.N.) had a slightly higher ratio than U.K. patients, and coloured patients had a much higher ratio.

(4) Irish patients had an exceptionally high ratio for white patients, and corresponded in this respect to the coloured patients.

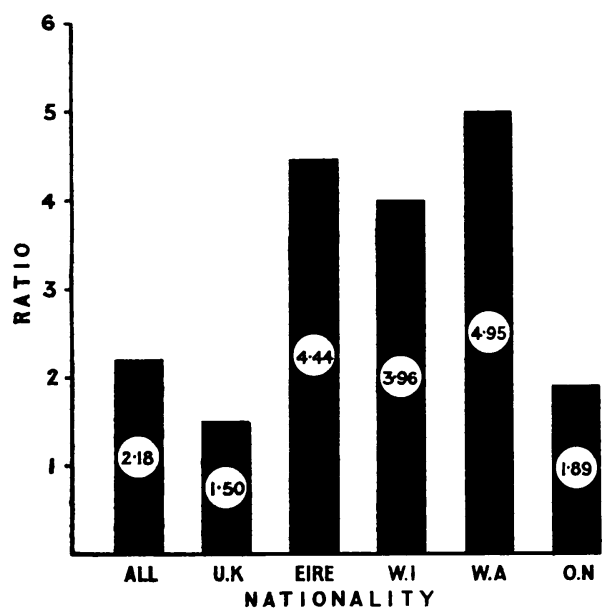

FIG. 11.-Gonorrhoea/NGU ratio, by nationality (Manchester clinics).

The GC/NGU ratio for the clinics in Manchester were compared with that of the patients treated in the peripheral clinics of the Manchester Regional Hospital Board Area for the years 1951 to 1957 inclusive. In the peripheral clinics the ratio is around unity and is only about half that obtaining in the Manchester city clinics (Fig. 12). That this difference is not solely due to the coloured and Irish patients seen in the Manchester clinics is shown in the ratios

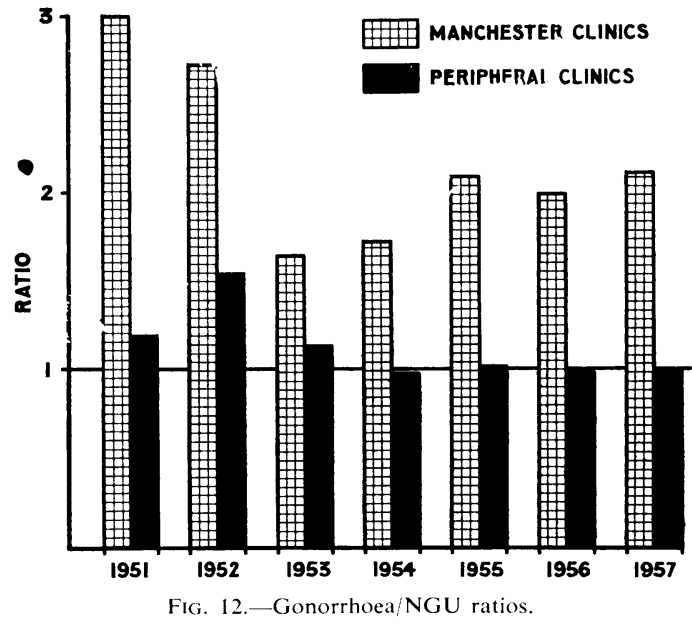

for 1956 and 1957. For these years, even when the ratio for U.K. patients alone is taken, it is still higher in the Manchester clinics than the ratio for the peripheral clinics (Table XVII).

TABLE XVII

GC/NGU RATIOS, BY YEAR, AND LOCALITY

\begin{tabular}{c|c|c}
\hline Year & Manchester & Peripheral Clinics \\
\hline 1951 & $3 \cdot 00$ & $1 \cdot 18$ \\
1952 & $2 \cdot 21$ & 1.54 \\
1953 & $1 \cdot 64$ & 1.13 \\
1954 & $1 \cdot 72$ & 0.98 \\
1955 & $2 \cdot 09$ & 1.01 \\
1956 & $1.99(1.42$ U.K. only) & 0.97 \\
1957 & $2 \cdot 14(1.61$ U.K. only) & 1.00 \\
\hline
\end{tabular}

These peripheral clinics serve the population of the smaller towns and their surrounding rural communities. The people in such areas generally live at home and have their own circle of friends; extramarital sexual relationships tend in such circumstances to be stable and there is little if any demand for the promiscuous woman who haunts the streets or pubs. In Manchester, by contrast, there are many men from the U.K., as well as from Eire, the West Indies, West Africa, and foreign countries, who are separated from home and stable friendships; in these circumstances, full employment, high wages, and lack of wisdom in the use of leisure combine to draw them to the city lights and pubs. The streets, pubs, and other places used by promiscuous women for meeting their clients are concentrated in wellknown areas in the centre of Manchester. The demand and supply of such facilities for promiscuity are almost non-existent in the smaller towns and rural areas, where sexual activity is probably relatively as great as in the big cities but is carried on 
within more stable relationships. NGU may arise from a stable sexual partnership, marital or extramarital, while gonorrhoea only flourishes amongst the promiscuous. I believe that this explains why gonorrhoea is the venereal disease of the big city, while NGU is relatively more common in the clinics serving smaller towns.

The GC/NGU ratio for U.K. patients in Manchester is weighted in favour of NGU because the U.K. figures include the NGU arising from stable sexual partnerships between local Mancunians. The white "other nationals" from Europe are less likely to establish stable partnerships, and consequently their GC/NGU ratio is higher than that for U.K. patients although their diagnostic pattern is otherwise similar.

The patient from Eire is young and usually single; he returns home from time to time and when he thinks of marriage his thoughts turn to a colleen near his home in the Emerald Isle. He lives in lodgings, often with a Catholic landlady who will not tolerate his bringing a woman to his room. For all these reasons he is unlikely to establish any stable sexual partnership. His choice of consort is frequently clouded by alcohol and exposure usually occurs outside, either with a prostitute met in the street between a pub and his lodgings or with an unknown woman with whom he has been drinking. I believe that these circumstances contribute to the high GC/NGU ratio found in Irish patients.

It is manifestly improbable that the West Indian or West African can establish a stable sexual partnership in Manchester. In the past year, judging from experience of antenatal cases, some West Indian women have joined their men folk in Manchester, but although this movement holds promise for the future, its extent is still too limited to have any real effect on the present promiscuity of the male West Indian. Numerous clubs for coloured men have sprung up in Manchester in the last few years and these are also patronized by promiscuous white girls, prostitutes or otherwise. These girls are lowclass, associate regularly with coloured men, and often spend some days in a man's room before passing on to another similarly short-lived liaison. As a consequence, a high proportion of these women are infected with gonorrhoea; they are particularly difficult to trace because of their itinerant habits and frequent change of name, and they seldom seek treatment until laid low with acute salpingitis. In these circumstances, the high $\mathrm{GC} /$ NGU ratio prevailing in the coloured patients is not surprising. Furthermore, the similarity of this ratio in the Irish and coloured patients will be seen to be due to the fact that their sexual outlets are found, albeit at different levels, in the same reservoir of gonococcal infection existing in the promiscuous section of the female population of the big city.

While these speculations may explain why men without stable sexual relationships are more likely to become infected with gonorrhoea, we still have to explain why these same men (Irish, West Indian, and West African) appear to suffer less frequently from NGU than U.K. citizens. I do not think it is because an underlying NGU is masked by concurrent gonorrhoea, because these nationalities do not present a residual NGU after penicillin treatment of gonorrhoea any more frequently than the U.K. patient. Nor do I think that the treatment of patients with gonorrhoea by general practitioners is extensive enough to have much influence on the GC/NGU ratio in U.K. patients. While it is difficult epidemiologically to believe that the promiscuous woman who spreads gonorrhoea should be less dangerous in respect of NGU than the nonpromiscuous female, is it perhaps possible that there is some biologic or metabolic antagonism between the gonococcus and the unknown agent or agents producing so-called non-specific urethritis? Incidentally, what evidence is there that the male case of NGU is infectious and able to transmit the unknown agent to the female? A direct racial susceptibility is an unlikely explanation, as the percentage of Irish seen with NGU is about as low as that of the coloured races. I think, however, that racial factors may indirectly provide a partial explanation. While gonorrhoea in the male nearly always produces a definite urethral discharge, the signs of infection with NGU vary widely from a definite purulent urethritis to an inconspicuous morning gleet. Recognition of the mildest cases will depend on the patient's powers of observation, introspectiveness, and general outlook on venereal disease. It will be shown later than the "O" patients are those who worry about V.D. after recent venereal exposure, and that such anxiety is largely confined to U.K. citizens and Europeans, who also provide relatively more cases of NGU. By contrast, coloured patients and especially the West African fall infrequently into this " $O$ " category and only attend with definite physical lesions. The Irishman occupies an intermediate position in the " $O$ " group, but is nearer to the coloured races than to the U.K. whites. It seems likely, therefore, that while most U.K. patients with NGU, both severe and mild, reach the clinic, only those Irish, West Indians, and West Africans with prominent symptoms seek treatment.

"N" Cases.-Why do white patients comprise 90 per cent. or more of those diagnosed " $N$ " 
(Table IV)? Why are coloured patients so seldom seen with the "N" conditions listed in Table II? I believe that the standard of personal hygiene and, in particular of genital hygiene, is the answer. How rare it is to see a coloured patient with balanitis, pyogenic infection of the skin, scabies, or pediculosis. Condylomata acuminata and herpes genitalis are sometimes seen in coloured patients, but it is my impression that both are less common than in whites. Another factor, but probably not an important one in this connexion, is that the coloured patient, particularly the West African, is less introspective than the white, and consequently minor conditions do not bring him to the clinics.

"O" Cases.-Patients diagnosed " $O$ " are usually those who are worried after a recent venereal exposure. Such anxiety is largely confined to U.K. citizens and Europeans (Table IV). The West African appears never to worry and the West Indian seldom comes to the clinic without a physical lesion. I have formed a tentative impression, however, that the West Indian is beginning to move nearer the U.K. citizen in this respect. If this trend develops we in Manchester are going to be kept very busy! The Irishman occupies a position between the coloured and the other white patients; venereal exposure causes him little anxiety unless physical signs develop when he often suffers severe anxiety and pangs of conscience,

Among the U.K. patients classified as "O", married men form a significantly large proportion48 per cent. (Table VI). The U.K. citizen is particularly likely to worry if he has had intercourse with a total stranger, whether exposure was free or was paid for in money (Tables XI and XII). When he has become acquainted over a few drinks in a pub, a subsequent exposure less often causes anxiety.

The Changing Position.-In making the foregoing generalizations, I do not wish to give a false impression that the position is static; in fact, in some respects, it is fluid. Experience at the M.R.I. clinic and at St. Luke's Clinic is not identical. First, the percentage of U.K. patients with gonorrhoea attending St. Luke's Clinic was about 50 per cent. in both 1956 and 1957; at the M.R.I. clinic, U.K. patients accounted for 53 per cent. of gonococcal infections in 1956 but only 33 per cent. in 1957. Secondly, at St. Luke's Clinic U.K. citizens made up 69 per cent. of all cases in 1956 and 68 per cent. in 1957. For the M.R.I. clinic the corresponding figure dropped from 64 per cent. in 1956 to 49 per cent. in 1957. Thus at the M.R.I. clinic there has been a relative decrease in the number of U.K. patients due to an absolute increase in Irish, West Indian, and West African patients. This increase in 1957 relates entirely to gonococcal infections, the numbers in the other diagnostic categories remaining essentially unchanged. The number of gonococcal infections treated during 1957 was 18 per cent. higher than in 1956 at St. Luke's Clinic and 27 per cent. higher at the M.R.I. clinic. U.K. and West Indian patients were mainly responsible for the increased numbers at St. Luke's Clinic, and West Indian, West African, and Irish at the M.R.I. clinic.

This increase in the number of gonococcal infections in the male in 1957 has, I understand, been a fairly general experience throughout the country, and $I$ also have evidence of a very slight increase in gonorrhoea in some of the peripheral clinics of the Manchester Regional Hospital Board area. The annual figures for gonorrhoea have been fluctuating since 1951, when the downward trend following the post-war peak became arrested, and I believe that such minor fluctuations are dependent on extraneous factors which include the state of the weather, economic and housing conditions, the local influence of national events, the existence of epidemics like influenza, public holidays, and other less discernible factors. These influences have operated in the past, but a recent factor which is certainly assuming large proportions in Manchester is that of "repeat" infections in a promiscuous minority. Coloured patients play a conspicuous part in the problem of "repeaters" which has recently been the subject of special study at St. Luke's Clinic (Watt, 1958). About one-fifth of the total of gonorrhoea infections in males treated during $1955(17.8$ per cent.) and 1956 (19.5 per cent.) represented "repeat" infections in individuals previously treated during these 2 years.

Infectious Syphilis.-Apart from one foreign seaman at the Seamen's Dispensary, no case of primary or secondary syphilis was seen in the Manchester clinics during 1957. Here again I believe that the situation is fluid, and that the present satisfactory position must not lead to complacency. The situation in Manchester is potentially explosive and should one or more of the promiscuous women who consort with coloured men become infected with syphilis it would be very difficult to prevent a serious outbreak.

Why has the incidence of syphilis declined so dramatically while that of gonorrhoea resists all our control activities? In males, the outward signs of syphilitic infection are obvious enough to bring the majority of primary and secondary stage cases to the clinics, and I believe therefore that the present 
rarity of early syphilis in the male is a firm pointer to its genuine absence in the population. After diagnosis, either infection responds well to penicillin in almost all cases; this fact suggests that the widespread use of antibiotics in general practice and hospital patients can be only a partial answer. The long incubation period of syphilis as compared with that of gonorrhoea hampers rather than helps direct control activity, as the male with a chancre often has little recollection of his consort of a month or more ago. I think, however, that the long incubation period of syphilis may indirectly be of supreme importance. In the immediate post-war period, both syphilis and gonorrhoea were common and were both frequently present in promiscuous women. In the early years of the penicillin treatment of gonorrhoea, short-acting aqueous preparations were used and dosage was often deliberately kept low in an attempt to avoid "masking" syphilis. By about 1950 , however, slow-release preparations were in use, and the dosage employed, although still quite modest, has been shown to be adequate to abort syphilitic infection during the earlier part of its incubation period. I am inclined to believe therefore, that by about 1950 the treatment of gonorrhoea in the male was providing a powerful controlling influence on the spread of syphilis. The infectious females missed by contact-tracing would in due course become noninfectious latent syphilitics or be brought to treatment through the dermatologist, laryngologist ophthalmologist, obstetrician, or other medical agency. The missed case of gonorrhoea in the female has no similar spontaneous trend to become noninfectious and, if promiscuous, continues to contribute to the reservoir of gonococcal infection. In addition, the aborting of syphilitic infection in males with gonorrhoea would reduce the number of new infections in the female. No similar protection against re-infection of the female with gonorrhoea by the promiscuous male exists. I believe that this goes some way to explain why the curves for gonorrhoea and syphilis abandoned in 1951 their previously parallel courses.

Reiter's Syndrome.-Harkness (1957) has referred to non-gonococcal urethritis as the major problem among the venereal diseases. I would agree with this view, at least in respect of the U.K. for several reasons, of which the development of Reiter's syndrome by a small percentage of NGU patients is one of the most important. This polyarthritis, whether or not it is accompanied by the eye and skin manifestations of the full syndrome, is now probably the most serious complication to which the venereal patient is liable. Its relationship to recurrent anterior uveitis, involvement of the sacro-iliac joints, and ankylosing spondylitis, is gaining wider recognition amongst ophthalmologists, rheumatologists, general physicians, and orthopaedic surgeons, and provides a good illustration of the many facets of medicine which the modern venereologist shares with his colleagues in other specialties. I advocate the closest possible liaison with these colleagues in the diagnosis, care, and rehabilitation of patients with Reiter's syndrome. The venereologist usually sees such cases earlier in the primary attack and has perhaps been less familiar with recurrent attacks and the later sequelae. On this occasion, however, I do not propose to speak about the clinical course of Reiter's syndrome, interesting as this undoubtedly is, but to say something about its epidemiology and the mechanism of its causation.

At St. Luke's Clinic, it was noticed in the late spring of 1956 that cases of Reiter's syndrome were being seen with unusual frequency, and we spoke loosely of an "epidemic" and of a "season" for Reiter's syndrome. A look-out was kept for a similar occurrence in 1957, but it did not materialize although sporadic cases were noted. I found that Professor Kellgren had also experienced an increase in cases of Reiter's syndrome at the Rheumatism Research Centre in 1956 and it therefore seemed desirable to explore the possibility of a seasonal factor. The records of the 18,135 male patients registered at St. Luke's Clinic between October 1, 1951, and September 30, 1957, were examined, and the notes of the 8,560 cases of urethritis were studied. These included 5,880 cases of gonorrhoea and 2,680 cases of NGU and revealed 59 examples of Reiter's syndrome (i.e. $2 \cdot 2$ per cent. of NGU cases and 0.7 per cent. of all cases of urethritis). I find that about 15 per cent. of gonorrhoea cases show NGU after penicillin treatment has eliminated the gonococcus, so that the number of persons with NGU, in which these 59 cases of Reiter's syndrome arose, was probably about $3,500(2,680+15$ per cent. of 5,880$)$, an incidence of 1.7 per cent. These percentages of incidence are, of course, minimal, as Reiter's syndrome may develop after default from the clinic and may not come to the notice of the venereologist. Analysis of these cases by the month of onset (Table XVIII, overleaf) showed that, although Reiter's syndrome could occur during any month of the year, there were peaks in April and June and again in the late summer. It seems, therefore, that there is no direct seasonal factor, and that the occurrence of Reiter's syndrome is more related to the incidence of NGU or of all cases of urethritis, and is associated with the greater sexual activities of the spring and the summer holiday season. Seventeen of these 59 cases 
were seen in 1956, exactly double the average annual incidence between 1951 and 1957 inclusive. Of these seventeen cases, eleven occurred between April and July (Table XVIII). This increase in cases of Reiter's syndrome was not associated with any undue increase in the number of urethritis cases reporting for treatment, and some additional factor seems to have been operative. Could this additional factor be related to the weather? Sir John Charles has stated that no summer since 1880 was colder, wetter, and duller than that of 1956 (Annual Report of the Chief Medical Officer to the Ministry of Health for 1956).

The polyarthritis of acute rheumatic fever is thought to arise from sensitization of the tissues following on tonsillar infection with a particular type of streptococcus in individuals who have an hereditary predisposition to rheumatic ailments; environmental and climatic factors may also play a part. Although this is perhaps an over-simplification, does Reiter's syndrome not present a fairly close parallel? The polyarthritis arises in persons with an infection of the genito-urinary or intestinal tract after a variable interval, during which sensitization of joint tissues may be taking place. It occurs in only a small percentage of persons suffering from NSU, but we do not know the cause or causes of NSU although most would agree that it is often infective in origin. In the same way as not all streptococcal infections produce rheumatic fever, perhaps only one type of the infective agent producing NSU is able to produce Reiter's syndrome. Hereditary predisposition to rheumatic complaints may also have a bearing on which patients with NSU develop Reiter's syndrome, and here a recent report of Reiter's syndrome in first cousins (Morton, 1958 ) is of great interest. In my experience, Reiter's syndrome is rarer in coloured than white patients, so that a racial factor may also be concerned. I believe that there may be a close parallel between the upper respiratory tract and the tonsils with their lymphatic and venous drainage on the one hand, and the urethra and prostate with their lymphatic and venous drainage on the other hand, in the causation of rheumatic fever and Reiter's syndrome. These fancies of mine about Reiter's syndrome are intentionally provocative and I hope that others will be stimulated to think about the many questions still unanswered about this fascinating condition.

\section{Conclusions}

This demographic study of the venereal patient in Manchester has provided figures of some interest to me and has raised questions which I have not been able fully to answer. However, the study was undertaken primarily to obtain an indication of the way in which efforts at V.D. control should be directed. A good deal of human suffering, chiefly mental, is represented by this series of patients, and this is particularly so in the NGU, N, and O cases. Can the incidence of these conditions, as well as that of gonorrhoea, be reduced?

The main conclusion is that three-quarters of all patients are exposed to venereal infection outside, having met their consort casually in the street or in a public house. The objective of the Wolfenden Committee recommendations is to drive the prostitute off the streets, and if this could be achieved a big step forward would have been made. I believe, too, that other promiscuous women not operating for money would also be discouraged from using the streets and other public places. Greater police activity could

TABLE XVIII

SEASONAL INCIDENCE OF REITER'S SYNDROME AT ST. LUKE'S CLINIC

\begin{tabular}{|c|c|c|c|c|c|c|c|c|c|c|}
\hline \multirow[t]{3}{*}{ Period } & \multirow{3}{*}{$\begin{array}{l}\cdots \\
\text { th }\end{array}$} & \multirow{3}{*}{$\cdots$} & \multicolumn{4}{|c|}{ October, 1951, to September, 1957} & \multicolumn{4}{|c|}{1956 Only } \\
\hline & & & \multicolumn{3}{|c|}{ Diagnosis } & \multirow{2}{*}{$\begin{array}{c}\text { Total } \\
\text { Urethritis }\end{array}$} & \multicolumn{3}{|c|}{ Diagnosis } & \multirow{2}{*}{$\begin{array}{c}\text { Total } \\
\text { Urethritis }\end{array}$} \\
\hline & & & $\begin{array}{c}\text { Reiter's } \\
\text { Syndrome }\end{array}$ & NGU & GC & & $\begin{array}{l}\text { Reiter's } \\
\text { Syndrome }\end{array}$ & NGU & GC & \\
\hline 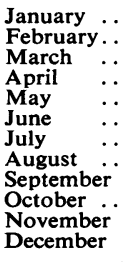 & $\begin{array}{l}\ldots \\
\ldots \\
\ldots \\
\ldots \\
\ldots \\
\ldots \\
\ldots \\
\ldots\end{array}$ & $\begin{array}{l}\ldots \\
\cdots \\
\cdots \\
\cdots \\
\cdots \\
\cdots \\
\cdots \\
\cdots \\
\cdots\end{array}$ & $\begin{array}{r}4 \\
1 \\
2 \\
7 \\
2 \\
11 \\
5 \\
6 \\
8 \\
6 \\
5 \\
2\end{array}$ & $\begin{array}{l}201 \\
162 \\
182 \\
253 \\
245 \\
255 \\
277 \\
263 \\
262 \\
217 \\
190 \\
173\end{array}$ & $\begin{array}{l}426 \\
381 \\
440 \\
458 \\
504 \\
521 \\
582 \\
614 \\
557 \\
521 \\
448 \\
428\end{array}$ & $\begin{array}{l}627 \\
543 \\
622 \\
711 \\
749 \\
776 \\
859 \\
877 \\
819 \\
738 \\
638 \\
601\end{array}$ & $\begin{array}{l}1 \\
- \\
3 \\
2 \\
4 \\
2 \\
1 \\
1 \\
1 \\
1 \\
1\end{array}$ & $\begin{array}{l}35 \\
31 \\
41 \\
47 \\
46 \\
28 \\
48 \\
32 \\
41 \\
44 \\
27 \\
22\end{array}$ & $\begin{array}{r}79 \\
34 \\
62 \\
67 \\
95 \\
92 \\
82 \\
87 \\
79 \\
103 \\
74 \\
72\end{array}$ & $\begin{array}{r}114 \\
65 \\
103 \\
114 \\
141 \\
120 \\
130 \\
119 \\
120 \\
147 \\
101 \\
94\end{array}$ \\
\hline Total & $\ldots$ & $\ldots$ & 59 & 2,680 & 5,880 & 8,560 & 17 & 442 & 926 & 1,368 \\
\hline
\end{tabular}

59 cases of Reiter's Syndrome in 2,680 cases of NGU $=2 \cdot 2$ per cent. 59 cases of Reiter's Syndrome in 8,560 cases of Urethritis $=0 \cdot 7$ per cent. 
discourage the act of intercourse in side streets and cul-de-sacs, which again would reduce "spur-of-themoment" exposures. This would involve less police work than might at first be thought, as the areas used by the promiscuous are quite circumscribed. Such legal action would expand the "call-girl" system which already exists to some extent in Manchester. This system, however, appears to give rise to less infection, requires deliberate and positive action by the male client, and facilitates case-finding. The public house is a national institution, and I have no quarrel with the vast majority but only with those few which are permitted by the management to be used almost exclusively as a rendezvous for prostitutes and other promiscuous women whose major objective is sexual intercourse. Such pubs are wellknown and are localized in the centre of the city; in them the exclusion from the general bar of unaccompanied women would be a major contribution to V.D. control. The clubs for coloured men constitute a problem which, however, is at present confined to a small if sexually active section of the community; here, better housing, better social and leisure time facilities, and greater immigration of West Indian women may provide the long-term solution. The ultimate control of venereal disease lies beyond the direct influence of the venereologist and will be both slow and difficult to achieve; at least in the larger cities, the venereologist still has much work ahead of him!

\section{Summary}

(1) A demographic study of 6,588 male patients attending the two major V.D. clinics in Manchester during 1956 and 1957 is reported. Of these, 40 per cent. had gonorrhoea (GC), 19 per cent. had nongonococcal urethritis (NGU), 16 per cent. had nonvenereal conditions requiring treatment ("N" cases), and 25 per cent. required no treatment other than reassurance (" $O$ " cases).

(2) These cases have been analysed with regard to diagnosis, nationality, age, marital status, place where consorts were met, place of exposure, and type of consort. The analysis shows that in males the following conclusions may be drawn:

(a) Half the gonococcal infections occur in persons born outside the U.K.;

(b) West Indians and West Africans account for one-third, and citizens of Eire and whites from other European countries for one-fifth of all gonococcal infections treated; (c) Only one in every twenty patients classified as " $N$ " or " $\mathrm{O}$ " is coloured;

(d) Four-fifths of "O" patients belong to the U.K.;

(e) For U.K. patients, one-third of the gonorrhoea cases and one-half of " $O$ " cases occurred in married men;

$(f)$ Three-quarters met their consorts casually in the street (45 per cent.) or public house (30 per cent.);

(g) Almost one-fifth met their consorts casually in clubs and dance halls;

(h) Irrespective of the place of meeting, the percentage distribution of conditions was remarkably similar;

(i) In over two-thirds, exposure took place outside;

( $j$ ) One-third paid the consort in money and one-fifth in kind ( 55 per cent. altogether).

(3) 87 per cent. of exposures occurred in Manchester or its immediate environs; the problem of V.D. control is thus a local one and importation of infection is insignificant.

(4) Sexual activity was greatest on Fridays, Saturdays, and Sundays.

(5) The gonorrhoea/non-gonococcal urethritis ratio varied markedly in Manchester between patients of different racial groups, ranging from 1.5 in U.K. patients to 4 and over in coloured patients. The ratio was higher in white patients in Manchester than in the peripheral clinics of the Region. Probable reasons for such differences are discussed.

(6) The V.D. situation appears to be fluid rather than static.

(7) A possible explanation is advanced why infectious syphilis has almost disappeared while the incidence of gonorrhoea has risen rather than fallen since 1951 .

(8) As three-quarters of all patients were exposed to venereal infection outside, having met a consort casually in the street or public house, and as over half the female consorts accepted payment in cash or kind, it is suggested that implementation of the recommendations of the Wolfenden Committee would make a significant contribution to V.D. 
control in Manchester. The exclusion of unaccompanied women from the general bars of public houses and greater police activity in the centre of the city against coitus in the open would also be helpful.

(9) The ultimate control of venereal disease lies outside the direct influence of the venereologist and will be both slow and difficult to achieve. At least in the major cities, the venereologist still has much work ahead of him.
I wish to thank Mr. J. Payton B.E.M., and Mr. A. Tattersall of St. Luke's Clinic for their help in the preliminary examination of the patients' records.

\section{REFERENCES}

Harkness, A. H. (1957). Brit. J. vener. Dis., 33, 208.

Laird, S. M. (1957). Ibid., 33, 242.

Ministry of Health. "Annual Report of the Chief Medical Officer for 1956". Cmnd. 325. H.M.S.O., London.

Morton, R. S. (1958). Brit.J. vener. Dis., 34, 50.

Watt, L. (1958). Ibid., 34, 9. 